\title{
PENGENALAN DASAR-DASAR AKUNTANSI BAGI SISWA RUMAH BELAJAR MAHKOTA KASIH INSANI
}

\author{
Henny Henny ${ }^{1}$, Olivia Dorothea Husin ${ }^{2}$ \\ ${ }^{1}$ Jurusan Akuntansi, Universitas Tarumanagara, Jakarta \\ Email: henny@fe.untar.ac.id \\ ${ }^{2}$ Jurusan Akuntansi, Universitas Tarumanagara, Jakarta \\ Email: olivia.125180524@stu.untar.ac.id
}

\begin{abstract}
Education for the younger generation is very important in increasing knowledge, creating creativity, and developing self-potential. Therefore, the Mahkota Kasih Insani Learning House in addition to funding students' schools also collaborates with external parties to provide initial knowledge for students from the foster children of the Mahkota Kasih Insani Learning House before facing learning activities at school. The collaboration is carried out by inviting lecturers and students of the Accounting Department, Faculty of Economics and Business, Universitas Tarumanagara, Jakarta to share knowledge in the field of accounting in community service activities. The purpose of this activity is to provide training on the introduction of the basics of accounting for students of the Mahkota Kasih Insani Learning House. The activity will be carried out on Saturday, July 3, 2021, offline with strict health protocols. This activity uses training methods regarding the introduction of accounting basics, accounting structures, basic accounting equations, and financial reports, as well as practice exercises about accounting basics. Based on the results of the activity evaluation, it can be concluded that community service activities run smoothly and give a good general impression for students because students can better recognize and understand the basics of accounting that are useful in dealing with learning activities in schools in the field of accounting
\end{abstract}

Keywords: Introduction, Basics, Accounting, Student

\begin{abstract}
ABSTRAK
Pendidikan bagi generasi muda sangat penting dalam menambah pengetahuan, menciptakan kreativitas, dan mengembangkan potensi diri. Oleh karena itu, Rumah Belajar Mahkota Kasih Insani selain membiayai sekolah siswa juga bekerjasama dengan pihak eksternal memberikan pengetahuan awal bagi siswa dari anak asuh Rumah Belajar Mahkota Kasih Insani.sebelum menghadapi kegiatan belajar di sekolah. Kerjasama yang dilakukan dengan cara mengundang dosen dan mahasiswa Jurusan Akuntansi Fakultas Ekonomi dan Bisnis Universitas Tarumanagara Jakarta untuk berbagi ilmu dibidang akuntansi dalam kegiatan pengabdian kepada masyarakat. Tujuan dari kegiatan tersebut adalah memberikan pelatihan pengenalan dasar-dasar akuntansi bagi siswa Rumah Belajar Mahkota Kasih Insani. Pelaksanaan kegiatan dilakukan pada hari Sabtu, 3 Juli 2021 secara luring dengan protokol kesahatan yang ketat. Kegiatan tersebut menggunakan metode pelatihan mengenai pengenalan dasar-dasar akuntansi, struktur akuntansi, persamaan dasar akuntansi, dan laporan keuangan, serta praktek latihan soal dasar-dasar akuntansi. Berdasarkan hasil evaluasi kegiatan, maka dapat disimpulkan kegiatan pengabdian kepada masyarakat berjalan dengan lancar dan memberikan kesan umum yang baik bagi siswa dikarenakan siswa dapat lebih mengenal dan memahami dasar-dasar akuntansi yang bermanfaat dalam menghadapi kegiatan belajar di sekolah dalam bidang akuntansi.
\end{abstract}

Kata kunci: Pengenalan, Dasar-Dasar, Akuntansi, Siswa

\section{PENDAHULUAN}

Pendidikan sangat penting bagi generasi muda, karena pendidikan ini bermanfaat dalam menambah pengetahuan, menciptakan kreativitas, dan mengembangkan potensi diri bagi generasi muda tersebut. Pengembangan pendidikan bagi generasi muda bukan hanya didukung oleh pemerintah, namun didukung oleh masyarakat di sekitar, seperti Rumah Belajar Mahkota Kasih Insani. Rumah Belajar Mahkota Kasih Insani adalah wadah yang memberikan pendidikan bagi masyarakat di sekitar melalui penerimaan generasi muda yang sulit membiayai sekolahnya yaitu siswa SMA/SMK. Rumah Belajar ini menampung siswa sebagai anak asuh dan mencari donatur untuk menjadi orang tua asuh dalam hal biaya sekolah siswa. 
Selain menampung siswa dan mencari donatur, Rumah Belajar Mahkota Kasih Insani juga berupaya menjalin kerjasama dengan pihak eksternal untuk memberikan pengajaran atau penambahan ilmu dalam bidang yang dipelajari siswa di sekolahnya. Oleh karena itu, Rumah Belajar Mahkota Kasih Insani bekerjasama dengan dosen Fakultas Ekonomi dan Bisnis Universitas Tarumanagara Jakarta untuk memberikan Pengabdian Kepada Masyarakat terkait bidang ilmu dosen tersebut yaitu bidang akuntansi. Kerjasama dengan pihak eksternal seperti ini juga dilakukan oleh Yayasan Kasih Mandiri Bersinar dimana pihak eksternal memberikan pengetahuan tentang perusahaan dan laporan keuangan yang harus disusun (Henny \& Ekadjaja, 2018).

Masalah yang dihadapi mitra adalah bekerjasama dengan pihak eksternal dalam memberikan pengajaran atau penambahan ilmu dalam bidang yang dipelajari siswa terutama akuntansi, karena siswa tersebut merupakan siswa SMK jurusan akuntansi. Oleh karena itu, Ibu Sofia Da Cunha selaku pimpinan Rumah Belajar Mahkota Kasih Insani mengundang Tim Pelaksana Pengabdian Kepada Masyarakat (PKM) yaitu Ibu Henny selaku Dosen Fakultas Ekonomi dan Bisnis Universitas Tarumanagara Jakarta bidang akuntansi bersama Olivia Dorothea Husin selaku mahasiswa jurusan akuntansi untuk memberikan pelatihan terkait Pengenalan DasarDasar Akuntansi Bagi Siswa Rumah Belajar Mahkota Kasih Insani. Solusi yang dapat diberikan oleh tim pelaksana adalah memberikan pelatihan dan penjelasan materi terkait dasar-dasar akuntansi.

Akuntansi memegang peranan penting bagi perusahaan. Oleh karena itu, akuntansi dapat disebut sebagai bahasa bisnis. Akuntansi memberikan informasi mengenai kinerja keuangan perusahaan, ataupun kondisi keuangan perusahaan pada suatu waktu tertentu (Setiawan, 2013:3). Akuntansi (Weygandt et al., 2016:2-3) terdiri dari tiga kegiatan aktivitas yaitu pengidentifikasian, pencatatan, dan komunikasi. Pengidentifikasian merupakan penseleksian setiap kejadian ekonomi (transaksi). Pencatatan merupakan proses mencatat, mengklasifikasi, dan merangkum setiap kejadian ekonomi tersebut. Sedangkan komunikasi merupakan proses menyiapkan laporan dan menganalisa serta menginterpretasikan bagi pengguna laporan.

Menurut Setiawan (2013:39) bahwa persamaan dasar akuntansi secara umum dapat dirumuskan sebagai berikut:

\section{HARTA = LIABILITAS + MODAL}

atau

\section{ASSETS $=$ LIABILITIES + OWNER'S EQUITY}

Rumus dalam konsep tersebut menjelaskan sisi kiri sebagai kekayaan entitas (suatu badan usaha) dan sisi kanan memaparkan bagaimana kekayaan entitas didanai (baik oleh utang atau modal sendiri). Dari persamaan tersebut dapat terlihat bahwa jika sisi kiri bertambah maka sisi kanan akan bertambah sebesar nilai yang sama atau diimbangi dengan penurunan sebesar nilai yang sama pada sisi kiri juga. Persamaan akuntansi ini merupakan kerangka kerja/framework terhadap pencatatan dan pengikhtisaran kejadian ekonomi (Yuniarwati et al., 2017:7).

Setelah persamaan dasar akuntansi, maka perusahaan dapat membuat laporan keuangan. Laporan keuangan dalam Pernyataan Standar Akuntansi Keuangan No. 1 (IAI, 2016:1.3) adalah suatu penyajian terstruktur dari posisi keuangan dan kinerja keuangan suatu entitas. Tujuan laporan keuangan adalah untuk memberikan informasi mengenai posisi keuangan, kinerja keuangan, dan arus kas entitas yang bermanfaat bagi sebagian besar pengguna laporan keuangan dalam pembuatan keputusan ekonomik. 
Sifat laporan keuangan menurut Kasmir (2014:11-12) adalah bersifat historis dan menyeluruh. Pencatatan yang dilakukan dalam penyusunan laporan keuangan harus dilakukan dengan kaidahkaidah yang berlaku.

\section{METODE PELAKSANAAN PKM}

Metode yang digunakan dalam pelaksanaan Pengabdian Kepada Masyarakat adalah metode pelatihan dengan topik pengenalan dasar-dasar akuntansi bagi siswa Rumah Belajar Mahkota Kasih Insani. Metode pelaksanaan ini diterapkan oleh tim pelaksana dengan memberikan materi yang terkait dengan: 1) Pengenalan dasar-dasar akuntansi; 2) Struktur akuntansi; 3) Persamaan dasar akuntansi; 4) Laporan keuangan; 5) Latihan soal dasar-dasar akuntansi. Pelatihan ini dilakukan secara luring dengan protokol kesehatan yang ketat.

Luaran yang dihasilkan dari pelaksanaan Pengabdian Kepada Masyarakat ini adalah publikasi hasil PKM berupa artikel yang diterbitkan pada jurnal atau dipresentasikan dalam seminar nasional yang diterbitkan pada buku prosiding.

\section{HASIL DAN PEMBAHASAN}

Kegiatan Pengabdian Kepada Masyarakat dilakukan pada hari Sabtu, 3 Juli 2021 mulai pukul $09.30 \mathrm{~s} / \mathrm{d}$ 11.30 WIB secara luring. Kegiatan yang dilakukan secara luring membuat tim pelaksana harus tetap menjaga protokol kesehatan dan menyiapkan hal-hal yang diperlukan dalam pelaksanaan PKM tersebut. Tim pelaksana PKM berangkat dari Universitas Tarumanagara Jakarta pada pukul 08.30 WIB menuju Rumah Belajar Mahkota Kasih Insani, Jl. Mayjen Soetoyo No. 18 RT.02/RW.01 Cililitan Besar, Kelurahan Cililitan, Kecamatan Kramat Jati, Jakarta Timur 13640. Kegiatan dimulai dengan acara pembukaan, doa pembukaan, pembagian materi, penjelasan materi, dan latihan soal dasar-dasar akuntansi. Peserta yang mengikuti kegiatan ini terdiri dari 5 orang siswa.

Pelatihan pengenalan dasar-dasar akuntansi bagi siswa rumah Belajar Mahkota Kasih Insani ini untuk meningkatkan pengetahuan siswa dalam menghadapi kegiatan belajar mengajar di sekolah yang akan dimulai pada tanggal 12 Juli 2021. Kegiatan PKM dibagi menjadi 2 (dua) sesi yaitu: Sesi 1: Pelatihan Pengenalan Dasar-Dasar Akuntansi dan Sesi 2: Latihan Soal Dasar-Dasar Akuntansi. Materi sesi 1 pengenalan dasar-dasar akuntansi terdiri dari dasar-dasar akuntansi, struktur akuntansi, persamaan dasar akuntansi dan laporan keuangan. Materi sesi 2 terdiri dari praktek latihan soal dari pemaparan materi sesi 1.

Setelah selesai 2 (dua) sesi tersebut, maka dilanjutkan dengan sesi evaluasi atas kegiatan PKM yang telah dilaksanakan dengan membagikan kuesioner kepada siswa Rumah Belajar Mahkota Kasih Insani. Berdasarkan hasil evaluasi yang telah diisi siswa tersebut bahwa:

1. Siswa menyatakan $100 \%$ sangat setuju untuk pelatihan pengenalan dasar-dasar akuntansi bermanfaat bagi siswa.

2. Siswa menyatakan $80 \%$ sangat setuju dan $20 \%$ setuju untuk pelatihan pengenalan dasardasar akuntansi menambah wawasan siswa.

3. Siswa menyatakan $40 \%$ sangat setuju dan $60 \%$ setuju untuk materi pelatihan pengenalan dasar-dasar akuntansi mudah dipahami siswa.

4. Siswa menyatakan $100 \%$ sangat setuju ingin mengikuti pelatihan sejenis dikemudian hari.

5. Siswa menyatakan $100 \%$ sangat setuju untuk kesan umum terhadap kegiatan PKM ini melalui pelatihan dasar-dasar akuntansi adalah baik. 


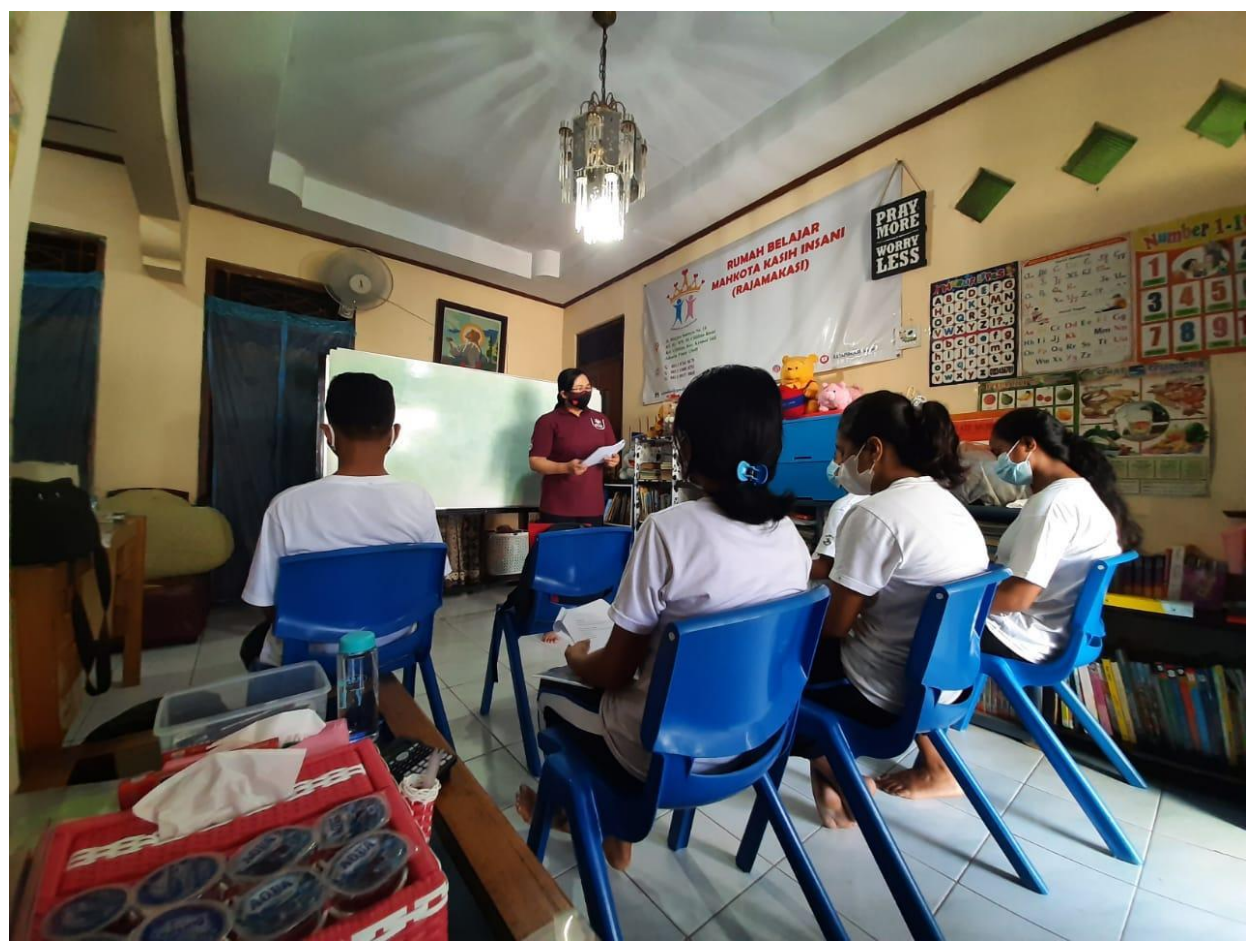

Gambar 1

Pelatihan pengenalan dasar-dasar Akuntansi oleh Ibu Henny

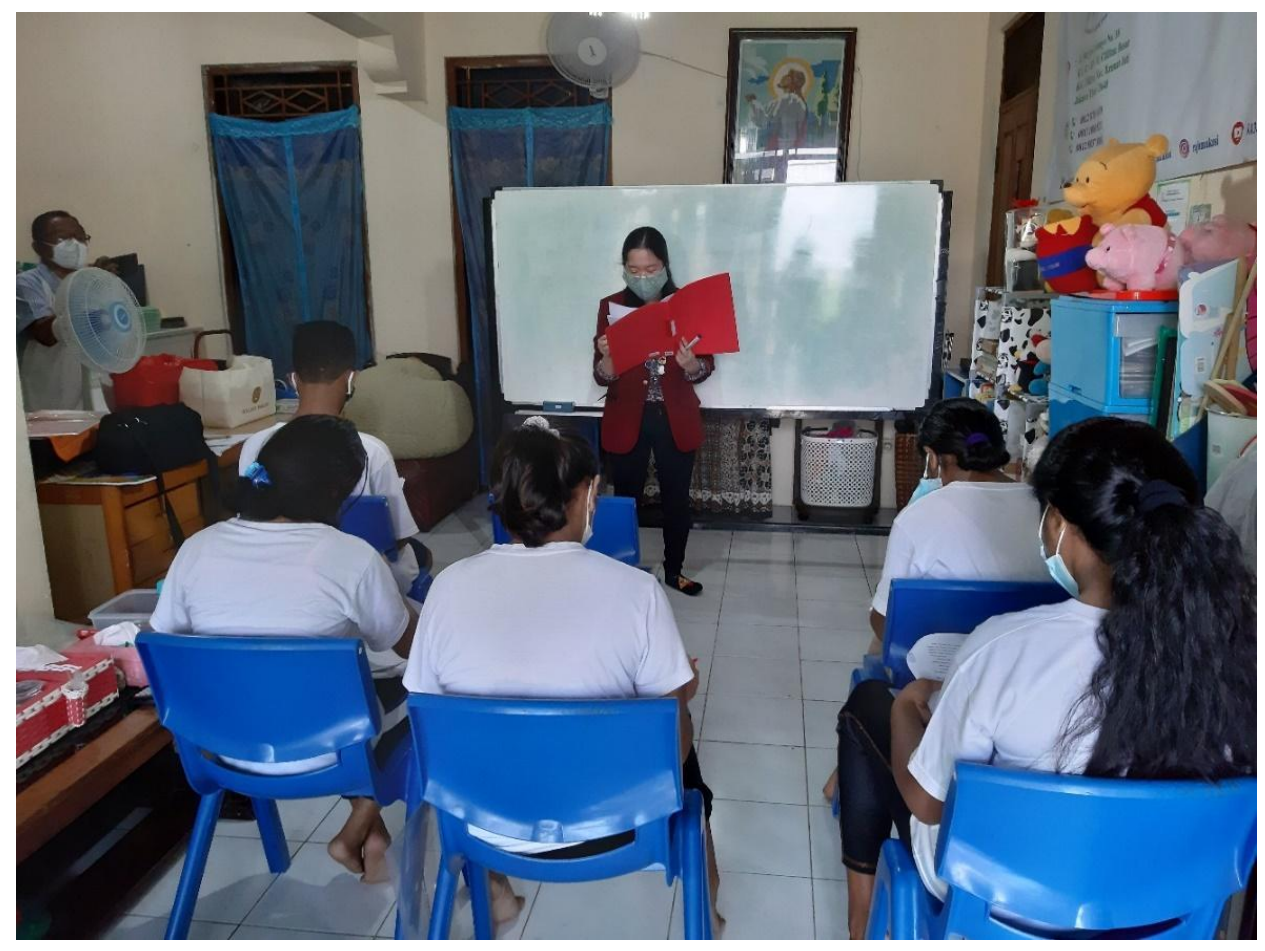

Gambar 2

Praktek Latihan soal pengenalan dasar-dasar Akuntansi oleh Olivia Dorothea Husin 


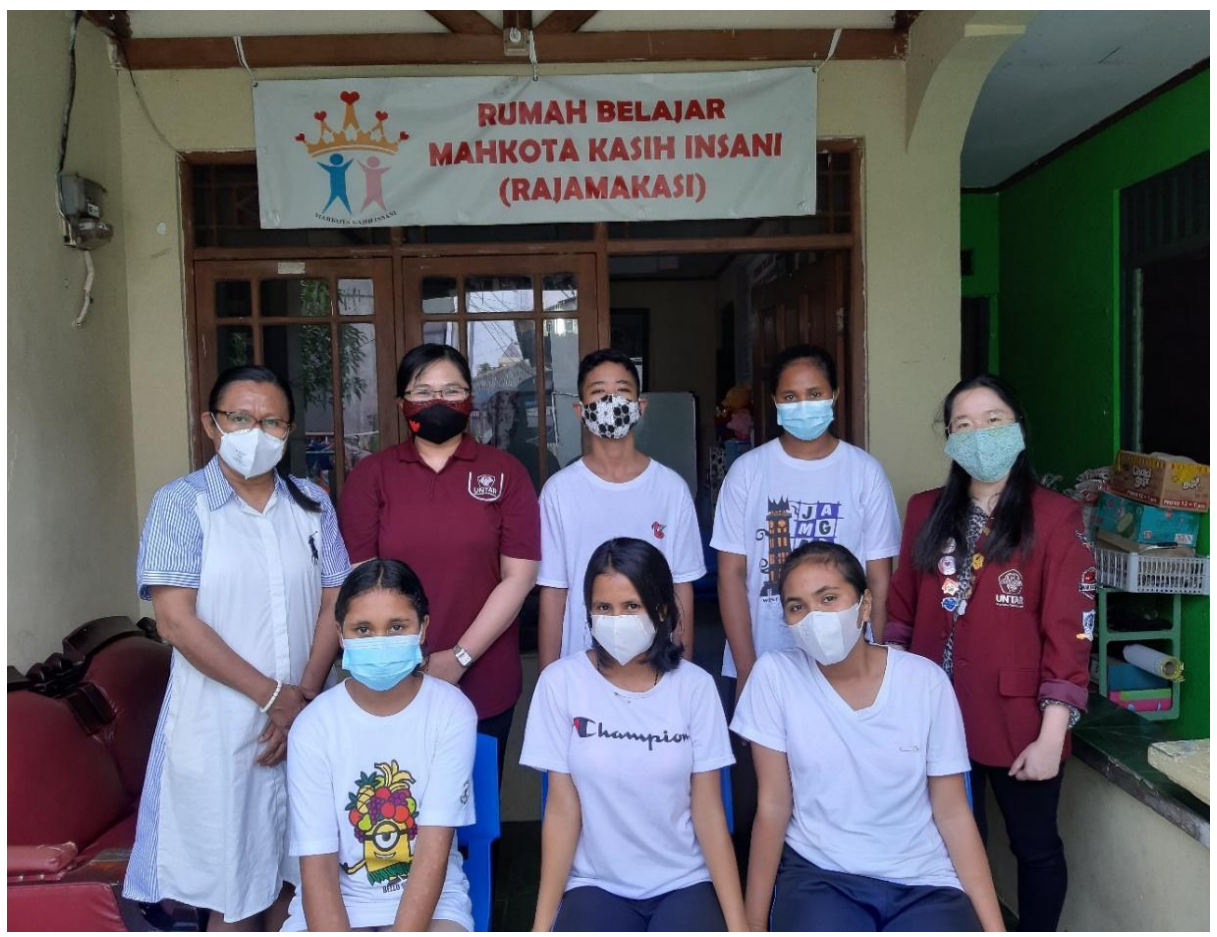

Gambar 3

Foto bersama pengurus, peserta, dan tim pelaksana PKM

Berdasarkan hasil evaluasi pelaksanaan kegiatan PKM diatas menunjukkan bahwa kegiatan PKM berjalan dengan lancar dan memberikan manfaat bagi siswa Rumah Belajar Mahkota Kasih Insani, sehingga memberikan kesan untuk memberikan pelatihan secara terus menerus kepada siswa tersebut, karena siswa dapat lebih mengenal dan memahami dasar-dasar akuntansi. Selain pelatihan yang diberikan oleh tim pelaksana PKM, tim juga memberikan sumbangan pembelian alat tulis dan kalkulator. Kegiatan ini didokumentasikan dalam foto-foto pelaksanaan Pengabdian Kepada Masyarakat dalam Gambar 1, 2 dan 3.

Gambar 1 memperlihatkan Ibu Henny sedang memberikan pelatihan pengenalan dasar-dasar akuntansi, struktur akuntansi, dan persamaan dasar akuntansi, serta penyusunan laporan keuangan. Gambar 2 memperlihatkan asisten pelaksana kegiatan PKM yaitu Olivia Dorothea Husin memberikan praktek latihan soal pengenalan dasar-dasar akuntansi untuk perusahaan jasa. Gambar 3 memperlihatkan foto bersama pengurus, peserta dan tim pelaksana PKM.

\section{KESIMPULAN DAN SARAN}

Pelaksanaan kegiatan PKM pada hari Sabtu, 3 Juli 2021 dapat disimpulkan berjalan dengan baik dan lancar, dikarenakan pelaksanaan PKM memberikan manfaat bagi siswa Rumah Belajar Mahkota Kasih Insani dalam lebih mengenal dasar-dasar akuntansi sebelum mereka memulai kegiatan belajar di sekolah.

Saran dari pelaksanaan PKM ini adalah sebaiknya pelatihan ini diadakan secara terus menerus untuk mendukung pemerintah dalam memberikan pendidikan bagi generasi muda.

\section{Ucapan Terima Kasih (Acknowledgement)}

Terima kasih kepada Lembaga Penelitian dan Pengabdian kepada Masyarakat (LPPM) Universitas Tarumanagara yang telah memberikan kontribusi dana pelaksanaan Pengabdian Kepada Masyarakat (PKM) kepada tim pelaksana sehingga pelaksanaan PKM ini dapat berjalan dengan lancar. 


\section{REFERENSI}

Henny, \& Ekadjaja, M. (2018). Pelatihan Penyusunan Laporan Keuangan Perusahaan Jasa di Yayasan Kasih Mandiri Bersinar. Prosiding Seminar Nasional Hasil Penelitian dan Pengabdian kepada Masyarakat (Senapenmas) 2018. Jakarta: Universitas Tarumanagara, 204-210.

Ikatan Akuntan Indonesia. (2016). Standar Akuntansi Keuangan Efektif Per 1 Januari 2017. Jakarta.

Kasmir. (2014). Analisis Laporan Keuangan. Jakarta: PT Rajagrafindo Persada.

Setiawan, T. (2013). Mahir Akuntansi: Buku Pengantar Akuntansi Untuk SMA dan Universitas. Edisi Revisi. Jakarta: PT Bhuana Ilmu Populer.

Weygand, J. J., Kimmel, P. D. \& Kieso, D. E. (2016). Accounting Principles. Twelfth Edition. Asia: John Wiley \& Sons (Asia) Pte Ltd.

Yuniarwati, Santioso, L., Ekadjaja, A. \& Rasyid, R. (2017). Pengantar Akuntansi 1 Belajar Mudah Akuntansi. Tangerang: PT Pustaka Mandiri. 